Vox Patrum 6/1986/z.10

\title{
NAUCZANIE JEZZYKA ŁACIŃSKIEGO W NOWYM PROGRAMIE SZKOŁY ŚREDNIEJ
}

Decyzją Ministerstwa 0światy i Wychowania z dnia 16 lipca 1981 r. został zatwierdzony do powszechnej realizacji nowy program Języka łacińskiego dla liceum ogólnokształcącego o profilu klasycznym w wymiarze 15 godzin tygodniowo /klasy I i II po 3 godziny, III - 5 godzin i IV - 4 godziny/ i humanistycznym oraz matematyczno-przyrodniczym w wymiarze 8 godzin tygodniowo. Program opracował Zespół Pedagogiczny Języka Lacińskiego w składzie: prof.dr Maria Cytowska, prof.dr Jerzy Lanowski, dr Wanda Popiak, mgr Irena Borzymińska - Majowa, mgr Jan Lasocki, mgr Tamara Simla 1 mgr. Jolanta Steckiewicz. Wydaje się, że Zespół nawiązał do uwag 1 postulatów, Jakie kilka lat temu wyłoniła powszechna dyskusja w polskich środkach przekazu, w której wypowiedzieli się o pożtku 1 potrzebie łaciny ludzie różnych zainteresowań i profesji. Program zakłada ambitne "cele kształcenia i wychowania" chçc zapewne wyrównać braki i szkody, jakie powstały w kulturze naszego pokolenia z powodu niedoceniania łaciny na rzecz wykształcenia technicznego.

Warto przyjrzeć się tym celom nowego programu. "Język łaciński jako jeden z elementów wykształcenia ogólnego odgrywa powszechną rolę w nauczaniu i przygotowaniu młodzieży do pracy 1 ustawicznej edukacji. Znajomość języka łacińskiego:

- pozwala lepiej zrozumieć zjawiska języka ojczystego, którego Pleksja i składnia ukształtowały się pod wpływem łaciny;

- ułatwia naukę języków nowożytnych dzięki możliwościom zrozumienia etymologii wielu wyrazów występujących w tych językach;

- budzi wrażliwość językora, wyrabia ścisłość wypowiedzi przez kształcenie umiejętności analizy jązykowej opartej na znajomości podstawowych zasad morfologii i składni łacińskiej;

- umożliwia poznanie kultury antycznej stanowiącej trwała vartość 
w rozwoju kultury europejskiej a szczególnie polskiej;

- przyczynia sie do gruntowniejszego rozumienia $i$ opanowania terminologit naukowej oraz technicznej, opartej w szerokim zakresie na językach klasycznych, co ułatwia pracę $w$ róznych zawodach 1 dyscyplinach nauk owych;

- wyrabia postawe humanistyczna dzieki treściom ldeowo-wychowawczym zawartym w tekstach - stwarza wiele okazji do wychowania aktywnych społecznie obywateli-patriotów.

Znajomość Języka łacínskiego 1 kultury antycznej będzie dla uczniów wielka pomocą nie tylko na lekcji języka polskiego 1 histori1, lecz równiez obudzi w nich wrazliwość estetycznaz 1 zainteresowanie dla zjawisk artystycznych w róznych dziedzinach ${ }^{1}$.

Zadanie Jezyka łacińskiego jako przedmiotu nie odbiega na ogóz od dotychczasowego. Chodz 1 o zaznajomienie uczniów z ok. 1000 słów 1 zwrotów lacińskich, przyswojenie niezbędnych elementów gramatyki w celu zrozumienta 1 tłumaczenła tekstów łacińskich przy pomocy słownika, wzbogacenie wiedzy o zyciu i kulturze narodów starozytnych oraz o kształtowanie umiejętności kojarzenia poznanych wyrazów lacińskich z pochodzącymí od nich w języku polskim i innych jezykach.

Treśc1 kształcenia 1 wychowania rozłożone na cztery klasy oparte sa na tekstach preparowanych, adaptoranych $i$ oryginalnych oraz poszerzone o czytanki polskie /nowośt/. Rozszerzono naukę o słowotwórstịie, etymologil 1 grupach wyrazowych. Fleksja $i$ składnia pozostaja bez zmian, ale wprowadzono 1 rozbudowano bardzo pozytywnie éwiczenia. Program podaje także "Zarys treści koła zainteresowan", który ukazuje możliwości pogłębienia treści kultury antycznej 1 doskonalenia jezyka w zakresie,np. bajki antycznej, teatru, architektury, inskrypcji 1tp. Przytacza się też przykładowe formy zajęć np. pogadank1 z przeźroczami, gry 1 zabawy językowe/zagadk1, rebusy/, nauka piosenek, inscenizacja sztuk plastycznych.

Ambitny program znalazł swoja realizację w wydanych dotąd dwóch podręcznikach dla klasy pierwszej 1 druglej, opracovanych przez

1 Ministerstwo 0światy 1 Wychowania. Instytut Programów Szkolnych, Język Laciński. Program Liceum Ogólnokształcącego/Profill humanistyczny/, Warszawa 1981,3 . 
Stanlezama Filozýaklego 1 Terese Zarych. T "Poradniku dla nauczyolela ${ }^{2}$ autorzy podkréslaja trud przygotomania 1 przepromadzenia l1cznych konsultaojl z zespozem takich speojalistó, jak: prop. K.Koped, doc.dr hab. H.Lyól1w100 1 recenzentów: prof. dr M.Brozek, prof.dr Z.Cytowska, prof.dr J.Lanowsk1, prof.dr J.Wikariak, prof. Z.Kw1eciriska 1 prof. Z.Sabizıo.

Poza dziewiecioma ozytankami polskimi, do których mozna zal1czyó takze plękny wstęp autoróm do podręoznika I klasy, nowosola jest układ jednostki metodycznej, złozonej z czterech czéci: 1/ prostych zdan laolnikich wprowadzajacych w nowe zagadnienio gramatyczne /ozę́́s $\Delta /, 2 /$ czytanki lacírakiej rozwijajacej nowe zjawisko gramatyozne /część B/, 3/ liczniejszych sentencji lacinskich 1 4/ óm1czer utrwalajzoyoh. N1e sposob jest przytoczyó tu licznych, jakze bogatyoh w doświadczente pedagoglozne objaśnień 1 wakazań w "Poradniku dla nauczyciela", ale uwazam za konieczne uwypuklí przynajmniej ozęéci A oraz " ewiczenlach wartośc1 dydaktyczne, stanowiace cenna nowość podreczników.

A oto niektóre przykłady:

Indicativus 1 infinitivus activi 1 passivi w lokoji $\mathrm{XII}^{3}$

a/ Anious me videt et salutat.

b/ Bgo ab amico videor et salutor.

Amicus te videt ot salutat. Tu ab amico videris ot salutaris.

/nastepuja przykłady kolejnych osob a tłumaczeniem polskim 1 podkreśleniem tłustym drukiem form biernych czasownikón/

Puto pueros, magistrum videre ot salutare.

Puto magistrun a pueris videri et saluteri.

Indicativus futuri I czasownikow III 1 IV koniugacj1 - lekoj1 2XIV:

Bgo herl discobam, nunc disco, cras discam,

Tu herl discebas, nunc disols, oras disces $/ 1$ dalsze przykłady/.

S1 multa loges et audies, multa cognosoes.

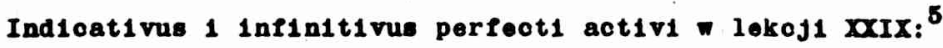

Puer laborat. Puer her1 laboravit.

Puerum laborare video. Puerum heri laboravisge solo /etc./

2 Leot1o Latina I. Poradnik dla nauczyciela, Marszama 1983, Vydawnlotwa Szkolne 1 Pedagogiczne, s.43.

3 Leotio Latina dla klasy I Licoum Ogólnokształcacego, Warszawa 1983, 1.43.

4 Tamze, 72.

5 Tamke, 84. 
Ćwiczenta wymagaja od ucznia przemyślenta 1 spostrzegawczości, a nade wszystko dokładnego poznania 1 zrozumienia czytanki. Częste przekłady z polskiego na lacinę pozwalaja sprawdzać osiagniety poziom wiedzy. Ponadto w cwiczeniach zawarte sa liczne zagadnienia słownictwa 1 słowotwórstwa. I znów tylko niektóre przykłady:

Ćwiczenie 3 z lekcji IX: ${ }^{6}$ - Przetłumacz na język polski:

Videsne discipulos laborare? Gaudetisne Marcum bonum amicum esse?

Cwiczenie 4 z tejże lekcj1: Przetłumacz na język laciński:

Uczniowie widzą, ze nauczyciel się cieszy.

Nauczyciel sądzi, ze uczeń myśl1.

Ciesze sie, ze piękna ksiązka podoba się uczniowi.

Cwiczenie 3 z lekcji $x^{\top}$ - Odpowiedz na pytania:

Quis in Forum Romanum properat?

Cui magister de Foro Romano narrat?

Quid Forum Romanum ornat?

Cwiczenie 4 z tejże lekcji: Przetłumacz następujace zdania na język laciński, stosując dat1vus possessivus:

Chłopiec ma piękną ksiązkę.

Pan ma wielu nlewolników.

Dziewczynka ma wiele przyjacíłek.

Cwiczenie 2 z lekoji ILII ${ }^{8}$ - Znając znaczente przedrostków: ad, de, ex, in, inter oraz znaczenie czasownika pono/kładę/ przyporządkuj następującym czasownikom łacińskim jedno z nizej podanyoh znaczeń: appono /z adpono/, depono, 1mpono/z 1npono/, expono, interpono - wyłozyć, wystawic, nakładac, wkładać, przyłożyć, przystawić, odłozycó, złożyé, wstawić, umieścić między czymó.

Czytank1 polskie będące fragmentami z dzieł mybitnych pisarzy polskich /Z1elińsk1, Parandowski/lub zagranicznych /Carcopino 1 1m./, rozbudzaja ciekawość uczniów takimi tematami, jak: Latarnia na Rodos, akwedukty, szlak bursztynowy, kalendarz 1 zegary 1tp. Wcześnie zaś mprowadzone teksty oryginalne utworów poetyckich przygotowuja ich

6 Tamze, 34 .

7 Tamze, 39 .

8 Tamze, 114. 
stopniowo do pełnego poznania zasad metryki łacińskiej:

- sentencje w heksametrze lub dystychu elegijnym,

- Bajki Fedrusa/Ezopa/ w trymetrze jambicznym,

- Carmina/Beatus ille/ Horacego w strofie jambicznej,

- Eneida /VI/ w heksametrze.

W składnlę miast wprowadzono wiele nazw miast współczesnych np.: Berolinum, -1 /Berlin/, Budapestinum,-i, Calisia,-ae, Cracovia,-ae, Posnania,-ae, Varsovia,-ae. W trudnośc1 ablativus absolutus wprowadza prosty a wymowny przykład:

Duobus litigantibus $=\left\{\begin{array}{l}\text { cum } \\ \text { quoniam } \\ \text { si } \\ \text { quamquam }\end{array}\right\}$ duo litigant tertius gaudet

Już druga lekcja ${ }^{9}$ mprowadza bardzo jasno w budowę pojedynczego zdania łacińskiego oraz podkreśla znaczenie funkcyjne w zdaniu przypadków rzeczownika. Lekcja zaś czwarta pokazuje jasno 1 przykładowo przy pomocy pytań o podmiot, orzeczenie, dopełnienie, przydawk okolicznik, jak powinna wyglądać poprawna analiza zdania, która bardzo ułatwia 1 doskonali technike tłumaczenia.

Z powyzszych rozwazań można również wyciągnąć pożyteczne wnioskı dla nauki języka łacı́nskiego w seminariach duchownych. Podręcznik1 trzech plerwszych klas pomagają w dobrym opanowaniu podstaw gramatyki 1 składni. W roku zaś czwartym zamiast lektury klasycznej nalezy wykorzystywać teksty biblijne $i$ patrystyczne znajdujące sie choćby w brewlarzu, o który nawet w dawnych wydaniach jest łatwo w kaźdym seminarium. Zasady metryki łacłńskiej moźna éw iczyć na hymnach, a latwe teksty psalmów 1 ksiag Starego Testamentu mogá stopniowo wprowadzać w trudniejszy język listów św. Pawła. Brewiarzowe lekcje patrystyczne 1 haglograficzne to dalsza sposobność do zapoznania się zarówno z proza artystycznaz womiliach ojców Kościoła, jak 1 historyczna w blografiach swietych. Przemyślenia zespołu kompetentnych pedagogów w programie 1 w podręcznikach moga być wreszcie pozytecznie wykorzystane równiez w postulowanym podręczniku do łaciny w wyzzych seminariach duchownych.

$$
\text { Ks. Władysław Golis - Częstochowa }
$$

9 Tamze, 13-14. 


\section{DE LINGUA LATINA}

IN SCHOLIIS MRDIIS POLONORUM SECUNDUM RECENS PROGRAMMA DOCENDA

$$
\text { /Argumentum/ }
$$

Hoo in breviseimo nunt10 soripto, qui annual1 sessione linguas classicas in Seminarifs Superioribus docentium a. 1985 in Lublin fusius referebatur, de recenti programmate docendi linguam Latinam In scholi1s medi1s a Polonorum Supremo Cons1lio Publicae Institutioni Praeposito constituto traotatur. 